\title{
RESEARCH
}

Open Access

\section{Potent bioactive methanolic extract of wild orange (Citrus macroptera Mont.) shows antioxidative, anti-inflammatory, and antimicrobial properties in in vitro, in vivo, and in silico studies}

Mousikha Lala', Debabrata Modak², Subhashis Paull ${ }^{2}$, Indrani Sarkar ${ }^{1}$, Ankita Dutta $^{3}$, Anoop Kumar ${ }^{3}$, Soumen Bhattacharjee ${ }^{2}$ and Arnab Sen ${ }^{1 *}$

\begin{abstract}
Background: There is always an increasing demand for natural remedies from natural sources which can substitute the synthetic therapeutic drugs and lessen their side effects. The present study aims to investigate the antioxidant, anti-inflammatory, antimicrobial properties and in silico docking study of Citrus macroptera leaf (CML) extract in both in vivo and in vitro aspect.

Material and methods: The antioxidant and anti-inflammatory potential of crude extract was investigated in vitro and in vivo on Wistar albino rat. The antioxidant potentiality also investigated on HepG2 cell line. Antimicrobial activity was evaluated against Staphylococcus sp. and Klebsiella sp. Chemical compounds of the crude extract were identified by GC-MS analysis. In silico docking was also done against NF-kB protein.
\end{abstract}

Results: At $200 \mu \mathrm{g} / \mathrm{ml}$ concentration, CML significantly scavenges reactive oxygen species (ROS) which was generated on HepG2 cell line. CML showed 71\% anti-inflammatory activity ( $p \leq 0.001)$ against carrageenan-induced paw edema in albino Wistar rats. CML extract is very effective against staphylococcus sp. than Klebsiella sp. In the docking analysis, the proximadiol and menthone had $-5.6 \mathrm{kcal} / \mathrm{mol}$ and $-5.7 \mathrm{kcal} / \mathrm{mol}$ binding affinity with the protein NF-kB.

Conclusion: In the present work, CML provided notable antioxidant, anti-inflammatory, and antimicrobial activity. This activity was confirmed by both in vitro and in vivo followed by in silico docking technique. Overall, the experimental results presented in this study suggest that crude extract of CML could be used as a promising antioxidant and antiinflammatory candidate with potential benefits.

Keywords: C. macroptera, Anti-inflammation, Antibacterial, HepG2 cells, Docking

\footnotetext{
* Correspondence: senarnab_nbu@hotmail.com

'Molecular Cytogenetics Laboratory, Department of Botany, University of

North Bengal, Siliguri, West Bengal, India

Full list of author information is available at the end of the article
}

\section{Springer Open}

( ) The Author(s). 2020 Open Access This article is licensed under a Creative Commons Attribution 4.0 International License, which permits use, sharing, adaptation, distribution and reproduction in any medium or format, as long as you give appropriate credit to the original author(s) and the source, provide a link to the Creative Commons licence, and indicate if changes were made. The images or other third party material in this article are included in the article's Creative Commons licence, unless indicated otherwise in a credit line to the material. If material is not included in the article's Creative Commons licence and your intended use is not permitted by statutory regulation or exceeds the permitted use, you will need to obtain permission directly from the copyright holder. To view a copy of this licence, visit http://creativecommons.org/licenses/by/4.0/. 


\section{Introduction}

Oxygen $\left(\mathrm{O}_{2}\right)$ is a significantly influential element for all aerobic organisms. There would be no existence of life without oxygen. However, at higher concentration, oxygen could be toxic to aerobes (Bulkley 1983). ROS, which contain oxygen, are chemically responsive molecules due to the presence of unpaired electrons and is the major cause of oxidative stress. Most of the vandalizing outcomes of oxygen is due to ROS, which include superoxide anion radicals $\left(\mathrm{O}_{2}{ }^{--}\right)$, hydroxyl radicals $\left(\mathrm{OH}^{*}\right)$, and non-free radical species such as ozone $\left(\mathrm{O}_{3}\right)$, hydrogen peroxide $\left(\mathrm{H}_{2} \mathrm{O}_{2}\right)$, and singlet oxygen $\left({ }_{1} \mathrm{O}^{2}\right)$ (Balaydin et al. 2010). It is generally well established that free radicals play a significant role in the progression of tissue attrition which is related to serious cell damage leading to inflammatory events (Bursal et al. 2013).

ROS increases abnormally during inflammation causing an imbalance between the oxidizing molecule and the antioxidant system of the body (Stadtman 1992). The humoral and cellular mechanisms of inflammation are innumerable and very complex. They involve gene regulatory factors such as the NF- $\mathrm{kB}$ and signaling substances synthesized by immune cells such as cytokines and prostaglandins (Ahmed 2011). Inflammation is triggered by many stimuli like pathogens and antigenantibody interaction (Osadebe and Okoye 2003). Besides, it is a protective response involving immune cells, blood vessels, and molecular mediators. Anti-inflammatory agents like non-steroidal anti-inflammatory drugs (NSAIDs), steroids, and immunosuppressants are often used for the repercussion of inflammation. But their use is often associated with serious side effects such as gastrointestinal bleeding and peptic ulcers (Corley et al. 2003). This has led to the search for alternative treatments (Cheung et al. 2007). In order to diminish the harmful effects of synthetic drugs, use of antioxidants directly procured from herbal products is very trustworthy because of their low side effects, low cost, and ready availability (Sheir et al. 2001).

Citrus macroptera Montr. is a semi-wild species of the family Rutaceae native to Malesia and Melanesia (Paul et al. 2015). It is alternatively known as Melanesian papeda, wild orange, hatkhora, and satkara (Hanelt 2001). In India, it is naturalized in the north-eastern part. There are reports regarding C. macroptera that the fruits exert anti-diabetic activity in experimental type 2 diabetic rats (Uddin et al. 2014). Moreover, C. macroptera fruit peel was shown to exhibit significant neuropharmacological effects against oxidative stress (Rahman et al. 2014).

However, no significant work has been done with $C$. macroptera leaf (CML) extract; especially so far, there is no report of antioxidant, anti-inflammatory, and antimicrobial properties of the extract. Therefore, in the present study, a detailed profiling of antioxidants has been done which is directly associated with oxidative stress-related diseases (Gross and Hen 2004). For further validation of in vitro results, we also checked the activity of CML in Wistar rat model (in vivo) followed by in silico docking for strong establishment of in vitro and in vivo results. Particular importance was also given to those bioactive chemical compounds which were identified in GC-MS analysis which might be responsible for its potent bioactivities.

\section{Material and methods}

\section{Collection and identification of plant materials}

The leaves were collected from the naturally growing plants from NBU Campus, Siliguri. The plant sample was identified by Plant Taxonomy and Biosystematics laboratory in the Department of Botany (Voucher specimen accession no-10333).

\section{Drugs, chemicals, and reagents}

Drugs, chemicals, and reagents used in the present study were of molecular biology and analytical grade and purchased from HiMedia Laboratories Pvt. Ltd., Mumbai, India; Merck, Mumbai, India or Thomas Baker, India. Diclofenac sodium was procured as Voveran-SR (Novartis India Ltd., Mumbai, India) and indomethacin (Jagsonpal Pharmaceutical Ltd., New Delhi, India) was purchased from drug suppliers.

\section{Preparation of extract}

Leaves were washed with tap water three times to remove the dirt. After soaking, they were crushed in grinder. Exhaustive extraction was performed in Soxhlet apparatus (plant material: solvent was $1: 10 \mathrm{~m} / \mathrm{v}$ ) for $6-7 \mathrm{~h}$ using methanol as solvent. The extract was then concentrated under reduced vacuum pressure at $40{ }^{\circ} \mathrm{C}$ in a rotary vacuum evaporator (Buchi Rotavapor R-3, Switzerland). Obtained concentrated extract was then stored in $-20^{\circ} \mathrm{C}$ for further use.

\section{Ethical statement}

All the experiments using animals were monitored, reviewed, and approved by the Animal Ethical Committee of Department of Zoology, NBU (Permit No. 840/ac/ 04/CPCSEA, Committee for the Purpose of Control and Supervision of Experiments on Animals).

\section{Animal maintenance}

Male Wistar albino rats were used for all the experiments. Animals were procured from authorized animal vendors of Kolkata, India. Adult rats $(n=5)$ were kept in polypropylene cages (Tarson, India), with paddy husk as bedding material. The experimental rats were maintained in the animal house of the Department of 
Zoology, University of North Bengal with sufficient food and water under a constant $12 \mathrm{~h}$ dark/light cycle at $24 \pm$ $2{ }^{\circ} \mathrm{C}$. The animals were acclimatized for at least 7 days prior to the initiation of the experiments.

\section{In vitro antioxidant assays}

\section{Determination of hydrogen donating ability (DPPH assay)}

The free radical scavenging activity through DPPH assay was performed following the method described by Saha et al. (2016) with minor modifications in extract concentration. Different concentrations $(50-200 \mu \mathrm{g} / \mathrm{ml})$ of the plant extract were prepared and mixed properly with freshly prepared DPPH solution (1 mM, diluted in 95\% methanol) and kept in dark. Optical density (OD) was measured at $517 \mathrm{~nm}$ using Bio-Rad micro plate reader and compared with the standard ascorbic acid. The percent of inhibition was calculated using the following Eq. (1):

$$
\text { Percent of scavenging }=\frac{A 0-A 1}{A 0} \times 100
$$

where $A_{0}=$ absorbance of the control and $A_{1}=$ absorbance in the presence of samples and standard.

And the $\mathrm{IC}_{50}$, i.e., half maximal inhibitory concentration values were calculated by the formula:

$$
Y=\frac{A 1}{X+A 1} \times 100
$$

where $A_{1}=\mathrm{IC}_{50}, Y=$ response $(Y=100 \%$ when $X=0)$, $X=$ inhibitory concentration.

\section{Determination of reducing power}

The Ferric reducing power assay was evaluated by the method of Saha et al. (2016) with slight alterations in extract doses. Different concentrations $(50-200 \mu \mathrm{g} / \mathrm{ml})$ of the plant extract $(500 \mu \mathrm{l})$ were mixed with $0.2 \mathrm{M}$ of phosphate buffer ( $\mathrm{pH} 6.6)$ and $0.1 \%$ of potassium hexacyanoferrate, followed by incubation at $50^{\circ} \mathrm{C}$ for $30 \mathrm{~min}$ in a water bath. After incubation, $500 \mu \mathrm{l}$ of TCA (10\%) was added to the mixture to stop the reaction. The upper aqueous portion of the reaction mixture was then transferred to another tube and mixed with $1 \mathrm{ml}$ of distilled water followed by $0.01 \%$ of $\mathrm{FeCl} 3$ solution. The mixture was left for $15 \mathrm{~min}$ at room temperature and the absorbance was measured at $700 \mathrm{~nm}$. Butylated hydroxytoluene (BHT) was used as standard.

\section{Metal chelating activity}

The chelating activity of ferrous ion by methanolic CML extract was determined by Saha et al. (2016) with slight alterations in extract doses. Various concentrations of CML extract $(50-200 \mu \mathrm{g} / \mathrm{ml})$ were mixed properly with ferrous sulfate $\left(\mathrm{FeSO}_{4}\right)$ solutions $(12.5 \mu \mathrm{M})$ in HEPES buffer ( $\mathrm{pH}$ 7.2) accompanied by the addition of ferrozine $(75 \mu \mathrm{M})$ to initiate reaction. The reaction mixture was trembled vigorously and incubated for $30 \mathrm{~min}$ at room temperature. The formed ferrous ion-ferrozine complex was measured at $562 \mathrm{~nm}$. EDTA was used as positive control.

\section{Hydroxyl radical scavenging assay}

Hydroxyl radicals generated on the basis of Fenton reaction $\left(\mathrm{Fe}^{3+}\right.$-ascorbate-EDTA- $\mathrm{H}_{2} \mathrm{O}_{2}$ system) were determined with little modifications in extract concentrations. A reaction mixture was prepared containing 2-D-ribose (3 $\mathrm{mM})$, monopotassium phosphate-potassium hydroxide buffer (KH2PO4-KOH, $25 \mathrm{mM}, \mathrm{pH}$ 7.4), ferric chloride $(\mathrm{FeCl} 3,100 \mu \mathrm{M})$, EDTA $(100 \mu \mathrm{M}), \mathrm{H}_{2} \mathrm{O}_{2}(1.0 \mathrm{mM})$, ascorbic acid $(100 \mu \mathrm{M})$, and various concentrations of extracts $(0-200 \mu \mathrm{g} / \mathrm{ml})$ up to a final volume of $2 \mathrm{ml}$ and the reaction mixture was left for $1 \mathrm{~h}$ incubation at $37^{\circ} \mathrm{C}$. Following incubation, $1 \mathrm{ml}$ of incubated mixture was taken into another tube and mixed with $1 \mathrm{ml}$ of TCA (2.8\%) and $1 \mathrm{ml}$ of aqueous TBA (1\%). The final mixture was incubated at $90^{\circ} \mathrm{C}$ for $20 \mathrm{~min}$ then cooled down to room temperature. The absorbance was measured at $532 \mathrm{~nm}$ against a blank solution. Mannitol was used as positive control. Hydroxyl radical scavenging activity was measured by aforesaid Eq. (1).

\section{NO radical scavenging activity}

NO radical scavenging assay was done by the procedure described by Saha et al. (2016) with changes in the extract concentrations. In brief, phosphate buffered saline $(\mathrm{pH}$ $7.4)$, sodium nitroprusside $(10 \mathrm{mM})$, and various concentrations of CML $(50-200 \mu \mathrm{g} / \mathrm{ml})$ were mixed to make final volume of $4 \mathrm{ml}$. After incubation for $1.5 \mathrm{~h}$ at $25^{\circ} \mathrm{C}, 0.33 \%$ of sulfanilamide (diluted in $20 \%$ of glacial acetic acid) was added to $0.5 \mathrm{ml}$ of the pre-incubated reaction mixture and left for $5 \mathrm{~min}$. Following the incubation, $1 \mathrm{ml}$ of $\mathrm{N}-(1-$ naphthyl)ethylenediamine dihydrochloride (NED, 0.1\%) was added and incubated for $30 \mathrm{~min}$ at $25^{\circ} \mathrm{C}$ to develop the color. The percentage inhibition was calculated using Eq. (1). The absorbance was measured at $540 \mathrm{~nm}$. Curcumin was used as positive control.

\section{Quantification of total phenol and flavonoid content}

Determination of total phenol content was determined by Folin-Ciocalteu method (Singleton and Rossi 1965). In short, $\mathrm{CML}$ extract $(100 \mu \mathrm{l})$ was mixed with FolinCiocalteu reagent (previously diluted 1000-fold with distilled water) and left for $5 \mathrm{~min}$ at room temperature followed by the addition of sodium carbonate $(0.06 \%)$ to the mixture. After incubation of $90 \mathrm{~min}$ at room temperature, the absorbance was measured at $740 \mathrm{~nm}$. The phenolic content was measured against a gallic acid standard curve $\left(R^{2}=0.986, y=0.007 \times-0.025\right)$. 
Total flavonoid content was determined according to aluminum chloride $\left(\mathrm{AlCl}_{3}\right)$ method (Zhishen et al. 1999) with slight modifications. CML extract $(100 \mu \mathrm{l})$ was added to $0.3 \mathrm{ml}$ of distilled water followed by addition of $5 \%$ sodium nitrate $\left(\mathrm{NaNo}_{2}\right)$. After 6 min of incubation at room temperature, $10 \% \mathrm{AlCl}_{3}$ was added and left for 5 min. The reaction mixture was then treated with $1 \mathrm{mM}$ of sodium hydroxide and lastly diluted with distilled water. Absorbance was recorded at $510 \mathrm{~nm}$. Data were reported as means \pm SD for 3 replications. The flavonoid content was measured against quercetin standard curve $\left(R^{2}=0.962, y=0.207 \times-0.204\right)$.

\section{In vitro test of inflammation}

\section{Collection of blood sample and preparation of erythrocyte suspension}

Erythrocyte suspension was prepared according to Modak et al. (2017). Briefly, fresh whole blood (3 ml) was collected from a healthy volunteer in an EDTA tube and was centrifuged (Sigma $3 \mathrm{~K} 30$ ) at $3000 \mathrm{rpm}$ for 10 min. The pellet was collected and the equivalent volume of normal saline $(0.9 \%)$ was mixed and then centrifuged to wash the RBC pellets thrice. Finally, the volume of the red blood pellets was measured and reconstituted as a $40 \%(\mathrm{v} / \mathrm{v})$ suspension with isotonic buffer solution $(\mathrm{pH}$ 7.4) to obtain the stock erythrocyte or hRBC suspension.

\section{hRBC membrane stabilizing activity}

Hypotonic solution-induced hemolysis The effect of the CML on hRBC hemolysis induced by hypotonic solution was assessed by the method of Shinde et al. (1999) and Modak et al. (2017). The dose values of extracts were modified according to our experimental designs. The experiments were carried out in triplicates for each experimental dose. First set of centrifuge tubes contained CML at a concentration of 250, 500, 750, and $1000 \mu \mathrm{g} / \mathrm{ml}$ in $5 \mathrm{ml}$ of hypotonic solution (distilled water), and in another set of centrifuge tubes, similar graded doses of the CML were prepared in isotonic buffer solution $(5 \mathrm{ml})$. In standard group, indomethacin $(200 \mu \mathrm{g} / \mathrm{ml})$ was used as a standard drug. One hundred microliters of stock erythrocyte suspension was then added to each of the centrifuge tubes and after gentle mixing, the mixtures were incubated for $1 \mathrm{~h}$ at $37^{\circ} \mathrm{C}$ temperature. After incubation, the mixture was centrifuged for $3 \mathrm{~min}$ at $1300 \mathrm{~g}$ in room temperature and the absorbance (OD) of the supernatant was measured at $540 \mathrm{~nm}$ using double beam UV-VIS spectrophotometer (Ray-Leigh UV-2601). The percentage of hemolysis was calculated by assuming the hemolysis produced in the presence of distilled water (hypotonic solution) to be $100 \%$. Thus the percent inhibition of hemolysis was calculated using the following equation. \%inhibition of hemolysis $=\left[1-\left(\mathrm{OD}_{2}-\mathrm{OD}_{1}\right) /\left(\mathrm{OD}_{3}-\mathrm{OD}_{1}\right)\right] \times 100$

where absorbance of test sample in isotonic solution $\left(\mathrm{OD}_{1}\right)$, hypotonic solution $\left(\mathrm{OD}_{2}\right)$, and absorbance of control sample in hypotonic solution $\left(\mathrm{OD}_{3}\right)$.

Heat-induced hemolysis This test was carried out with the standard protocol described by Shinde et al. (1999) and Modak et al. (2017). Briefly for this test, control, experimental CML treated groups and one standard drug group were considered. The centrifuged tubes were arranged in triplicates per dose. First set, designated as control tubes contained only $5 \mathrm{ml}$ of the distilled water (vehicle). In experimental groups, CML was dissolved in $5 \mathrm{ml}$ of isotonic phosphate buffer solution $(\mathrm{pH} 7.4)$ at a concentration of $250,500,750$, and $1000 \mu \mathrm{g} / \mathrm{ml}$. The standard drug dose group contained $5 \mathrm{ml}$ isotonic buffer solution containing indomethacin at a concentration of $200 \mu \mathrm{g} / \mathrm{ml}$. An amount of $100 \mu \mathrm{l}$ of erythrocyte suspension was added to each tube and mixed gently. The tubes were incubated at $54{ }^{\circ} \mathrm{C}$ for $20 \mathrm{~min}$ in a regulated water bath. After incubation period, the reaction mixture was centrifuged at $1300 \mathrm{~g}$ for $3 \mathrm{~min}$ in room temperature and the absorbance (OD) of the supernatant was measured at $540 \mathrm{~nm}$. The percent inhibition of hemolysis by the CML was calculated using the following equation.

$$
\text { \%inhibition of hemolysis }=\left(\mathrm{OD}_{2}-\mathrm{OD}_{1}\right) / \mathrm{OD}_{2} \times 100
$$

where absorbance of heated test sample $\left(\mathrm{OD}_{1}\right)$ and heated control sample $\left(\mathrm{OD}_{2}\right)$

\section{In vivo test of inflammation}

\section{Acute toxicity test}

Acute toxicity test were performed according to the OECD guideline 423 for acute oral toxicity study in rodents. The mortality rate, salivation, food and water intake, fur irritation, lethargy, and loss of body weight were observed for $24 \mathrm{~h}$ after the treatment. The rats were kept under observed for up to 7 days for any late sign of toxicological effects.

\section{Carrageenan-induced paw edema in rat}

The anti-inflammatory activity of CML was evaluated using carrageenan-induced paw edema restoration experiment in rats, described by (Gupta et al. 2006) with modifications in dose value of extracts. A total 25 numbers of Wistar albino rats were randomly divided into 5 groups each having five animals. The group 1 (vehicle group) indicated normal animals; group 2 indicated negative control group where paw edema was induced; groups 3 and 4 (low and high-dose groups respectively) were treated with $250 \mathrm{mg} / \mathrm{kg}$ b.w. and $500 \mathrm{mg} / \mathrm{kg}$ b.w. dose of CML treated orally once on a day after the paw edema was induced; and group 5 indicated standard 
drug group where paw edema was induced and standard diclofenac sodium (10 mg/kg of b.w.) (Gupta et al. 2015) was fed as an anti-inflammatory drug.

On the experimental day, following the pre-treatment with CML ( $1 \mathrm{~h}$ before) and $0.9 \%$ carrageenan injection $(0 \mathrm{~h})$, the swelling of the paw was recorded by measuring the paw circumference (in $\mathrm{mm}$ ) using a vernier calliper immediately before pre-injection and at selected intervals at 0.083 ( $5 \mathrm{~min}), 1.083$ ( $1 \mathrm{~h} 5 \mathrm{~min}), 2.083$ ( $2 \mathrm{~h} 5 \mathrm{~min}$ ), 3.083 ( $3 \mathrm{~h} 5 \mathrm{~min}$ ), 4.083 ( $4 \mathrm{~h} 5 \mathrm{~min}$ ), and 5.083 ( $5 \mathrm{~h} 5$ $\mathrm{min}$ ) hours after the carrageenan injection. Percentage of inhibition was calculated using following formula:

$$
\begin{array}{r}
\text { \%inhibition }=\left[\left(C_{\mathrm{t}}-C_{0}\right)_{\text {Negative control }}-\left(C_{\mathrm{t}}-C_{0}\right)_{\text {Treatment }}\right] \\
/\left(C_{\mathrm{t}}-C_{0}\right)_{\text {Negative control }} \times 100
\end{array}
$$

Where $\left(C_{\mathrm{t}}-C_{0}\right)$ Negative control is the difference in the paw circumference in $5.08 \mathrm{~h}$ in negative control rats and $\left(C_{\mathrm{t}}-C_{0}\right)$ Treatment is the difference in the size of paw circumference at $5.08 \mathrm{~h}$ in rat either treated with $\mathrm{CML}$ or standard drug.

\section{Detection of intracellular ROS generation}

$\mathrm{H}_{2}$ DCFDA is used for the detection of hydrogen peroxide production in normal cells. Standard protocol (Wu and Yotnda 2011) was followed with slight modification for measurement of intracellular ROS. The oxidation of 2,7-dichlorofluorescein $\left(\mathrm{H}_{2} \mathrm{DCF}\right)$ to 2,7-dichlorodihydrofluorescein $\left(\mathrm{H}_{2} \mathrm{DCFDA}\right)$ was used for the determination of hydrogen peroxide $\left(\mathrm{H}_{2} \mathrm{O}_{2}\right)$. Human liver cells (HepG2) were selected for the study and grown on cover slip in $35 \mathrm{~mm}$ Petri dishes and incubated for $24 \mathrm{~h}$ with $5 \% \mathrm{CO}_{2}$ in $\mathrm{N}$-biotech incubator. After $24 \mathrm{~h}$ incubation, HepG2 cells were treated with the highest experimental concentration of CML extract (dissolved in DMSO at $200 \mathrm{mg} / \mathrm{mL}$ ). Control plate was kept without treatment with the CML extract. Cells were incubated for $24 \mathrm{~h}$ at the same conditions as given above and washed twice with phosphate buffer saline (PBS). Fresh serum media was added with $25 \mathrm{mM}$ 2,7-dichlorofluoresceindiacetate and incubated for $30 \mathrm{~min}$ in the $\mathrm{CO}_{2}$ incubator. Immediately after incubation, HepG2 cells were washed thrice with serum free media and glass slides were prepared by inverting cover slips on the slide in $20 \%$ glycerine/PBS solution. Cells were observed under LED-based fluorescence microscope (Magnus MLXi) and excited at $480 \mathrm{~nm}$ using LED cassettes and emission was collected using a long pass filter. The cells were observed at $\times 10$ magnification and images were captured by digital SLR Olympus camera mounted on the head for high-resolution image.

\section{Microbiological screening}

Antimicrobial activity of methanolic CML extract was evaluated by the agar well diffusion method which was modified by Olurinola (1996), and minimum inhibitory concentration (MIC) was determined by Akinyemi et al. (2005).

\section{Culture and maintenance of microorganism}

One gram positive (Staphylococcus sp.) and one gramnegative (Klebsiella sp.) bacteria were used in this experiment. The pure cultures of bacterial were maintained on nutrient agar $[40 \mathrm{~g} / \mathrm{L}]$ medium. Each bacterial culture was further maintained by subculturing regularly on the same medium, incubated at $37{ }^{\circ} \mathrm{C}$ for $24 \mathrm{~h}$ and finally stored at $4{ }^{\circ} \mathrm{C}$ before use in this experiment.

\section{Screening for antibacterial activity}

For agar well diffusion method, antimicrobial susceptibility was tested using media prepared with agar $(20 \mathrm{~g} / 1$ $\mathrm{L})$ and $\mathrm{MH}$ broth $(21 \mathrm{~g} / 1 \mathrm{~L})$ in $1 \mathrm{~L}$ conical flask. The media prepared was then sterilized by autoclaving at $120^{\circ} \mathrm{C}$ for $20 \mathrm{~min}$.

Petri plates were prepared by pouring $25 \mathrm{ml}$ of media. Petri plates were allowed to stand for $30 \mathrm{~min}$ for solidifying the media completely. Freshly prepared bacterial inoculums [diluted 1:1 with sterile water] was then evenly spread using a sterile cotton swab upon the entire agar surface. A $6 \mathrm{~mm}$ hole was then punched with a sterile cork borer and a $100 \mu \mathrm{l}$ volume of each plant extract with a concentration of $10 \mathrm{mg} / \mathrm{ml}$ was pipetted into triplicate wells. The plates were incubated at $37^{\circ} \mathrm{C}$ for $24-$ $48 \mathrm{~h}$ and the inhibition zone diameter was taken in three different fixed directions and the average value was recorded. DMSO (dimethyl sulfoxide) served as control.

\section{Determination of the MIC}

One hundred microliters of extract with different concentrations $[0.5 \mathrm{ul} / \mathrm{ml}-10 \mathrm{mg} / \mathrm{ml}]$ was poured into the well. Petri plates were incubated overnight at $37^{\circ} \mathrm{C}$. Parallelly controls were run in which the solvent [DMSO] of the plant extract was dissolved. The plates were observed for inhibition zones after $24 \mathrm{~h}$ and the readings were measured in three different fixed directions and the average values were recorded accordingly.

The antimicrobial activity of selected compounds obtained from GCMS analysis was considered for docking analysis. The FtsZ protein of Staphylococcus aureus was taken as our target. FtsZ is a very special protein involved in cell division and is one of the major housekeeping genes of microbes (Guan et al. 2018). The pdb format of this protein (PDB id 3VOB) was downloaded from RSCB PDB databank. In silico docking analysis was done through the Autodock vina software. 


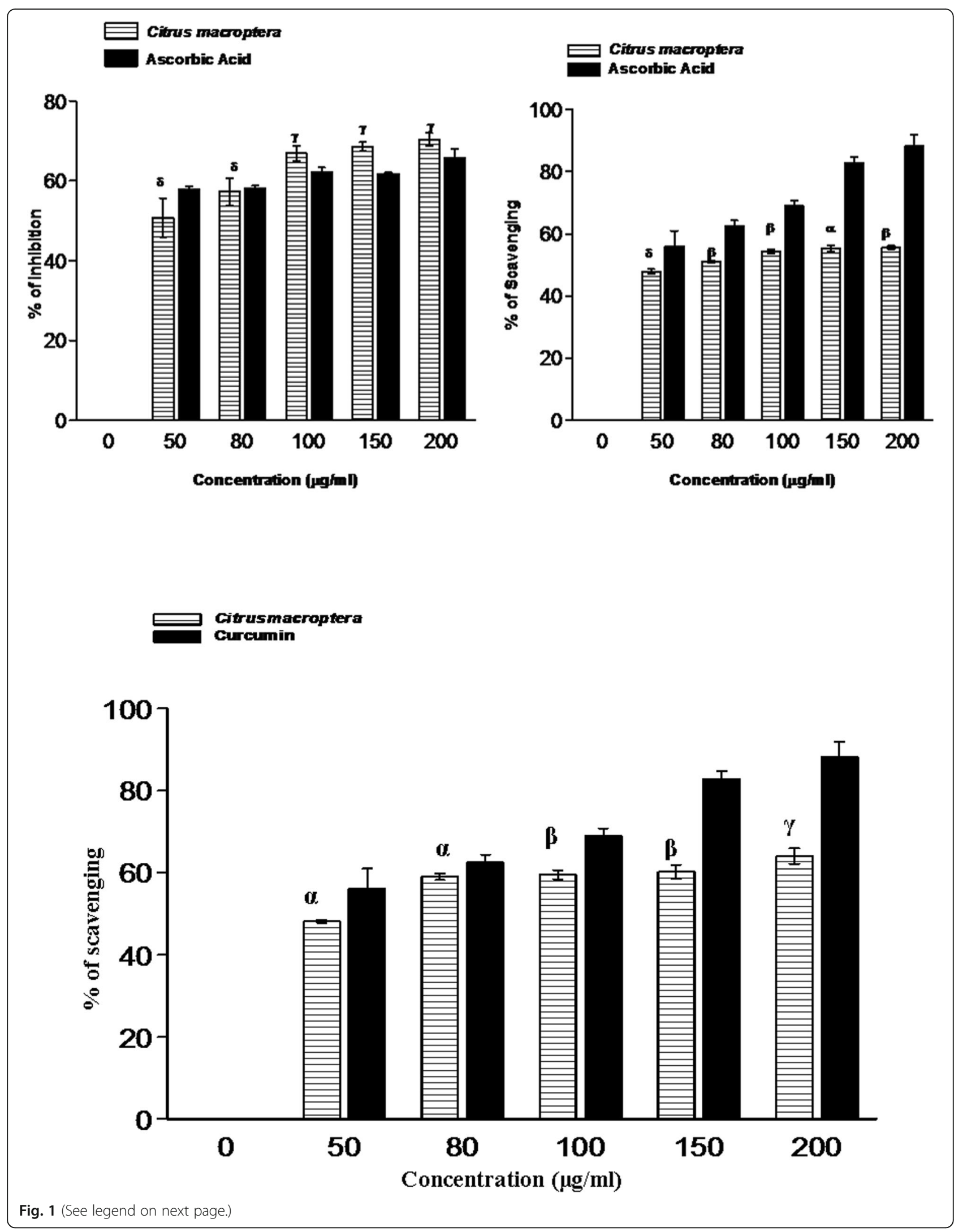


(See figure on previous page.)

Fig. 1 Antioxidant and free radical scavenging activity of CML extract. a DPPH radical scavenging activity (\% of inhibition $=70.35 \pm 1.6 \mathrm{at} 200 \mu \mathrm{g} /$ $\mathrm{ml}, \mathrm{IC} C_{50}=58.47 \pm 2.27 \mu \mathrm{g} / \mathrm{ml}$ ); $\mathbf{b}$ hydroxyl radical scavenging activity (\% of inhibition $\left.=55.68 \pm 0.5 \mathrm{at} 200 \mu \mathrm{g} / \mathrm{ml}, \mathrm{IC} C_{50}=91.14 \pm 1.1 \mu \mathrm{g} / \mathrm{ml}\right) ; \odot$ Nitric oxide reducing activity (\% of inhibition $=63.96 \pm 1.8$ at $200 \mu \mathrm{g} / \mathrm{ml}$, IC50 $=70.87 \pm 0.87 \mu \mathrm{g} / \mathrm{ml}$ ); where $a=p<0.05 B=p<0.01, \gamma=p<$ $0.001, \delta=$ non-significant when compared to standard

\section{GC-MS analysis}

The bioactive compounds of CML extract were identified by GC-MS analysis according to standard methods with slight modifications (Dey et al. 2015). Thermo Scientific Trace 1300 GC, equipped with ISQ-QD (Thermo Scientific) single quadruple mass analyzer and TG-5MS column $(30 \mathrm{~m} \quad 3 \quad 0.25 \mathrm{~mm} 3$ $0.25 \mathrm{~lm}$ ) were employed for the identification of bioactive compounds. ThermoXcaliburTM software version 2.2 was used to analyze all the samples. Automated Mass Spectral Deconvolution and Identification System (AMDIS) version 2.70 was applied for the interpretation of MS data.

\section{In silico docking}

Carrageenan is well known for inducing the inflammatory response in animal models and human through activation of NF-kB with increased IL-8 production
(Borthakur et al. 2012). Hence, we selected a structure of the nuclear factor kappa-b (nf-kb) p50 homodimer from Rattus rattus for our docking study. The X-ray diffraction structure of this protein (PDB id INFK) was obtained from PDB database (https://www.rcsb.org/ structure/1nfk). The resolution of this structure was 2.3 $\AA$ which is good enough for docking study. CASTp server (http://sts.bioe.uic.edu/castp/) was used for active site and pocket prediction. The protein was finally prepared for docking after removing the water molecules and adding polar hydrogens. Relevant phytochemicals obtained and identified from the GC-MS analysis were used as ligands. Structures of those ligand molecules were downloaded from in sdf format NCBI PubChem database. Those structures were converted to PDB format through SMILES server. Autodock Tool 1.5.6 software was used for grid-based docking and results were visualized through PyMol version 1.7.4.

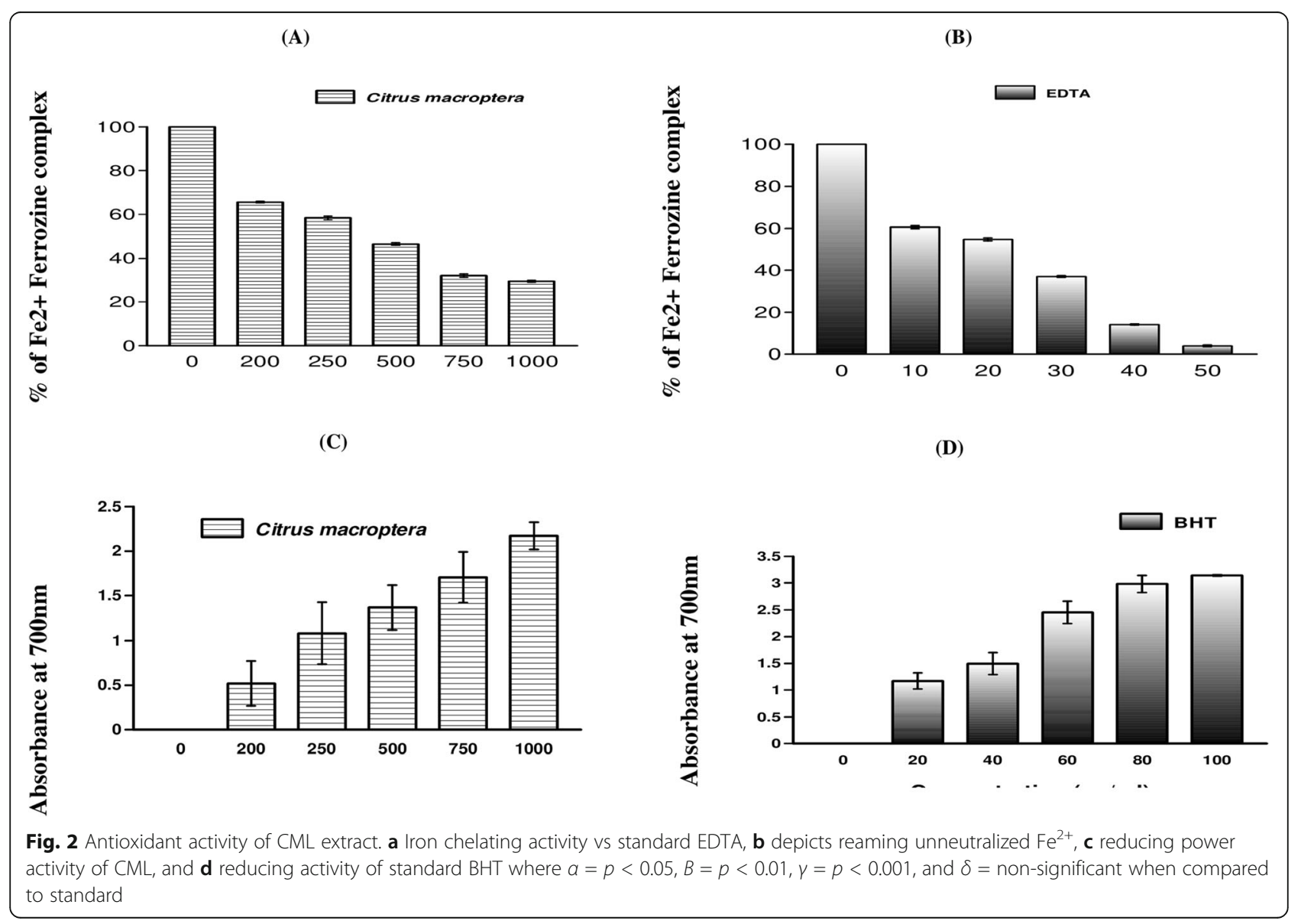



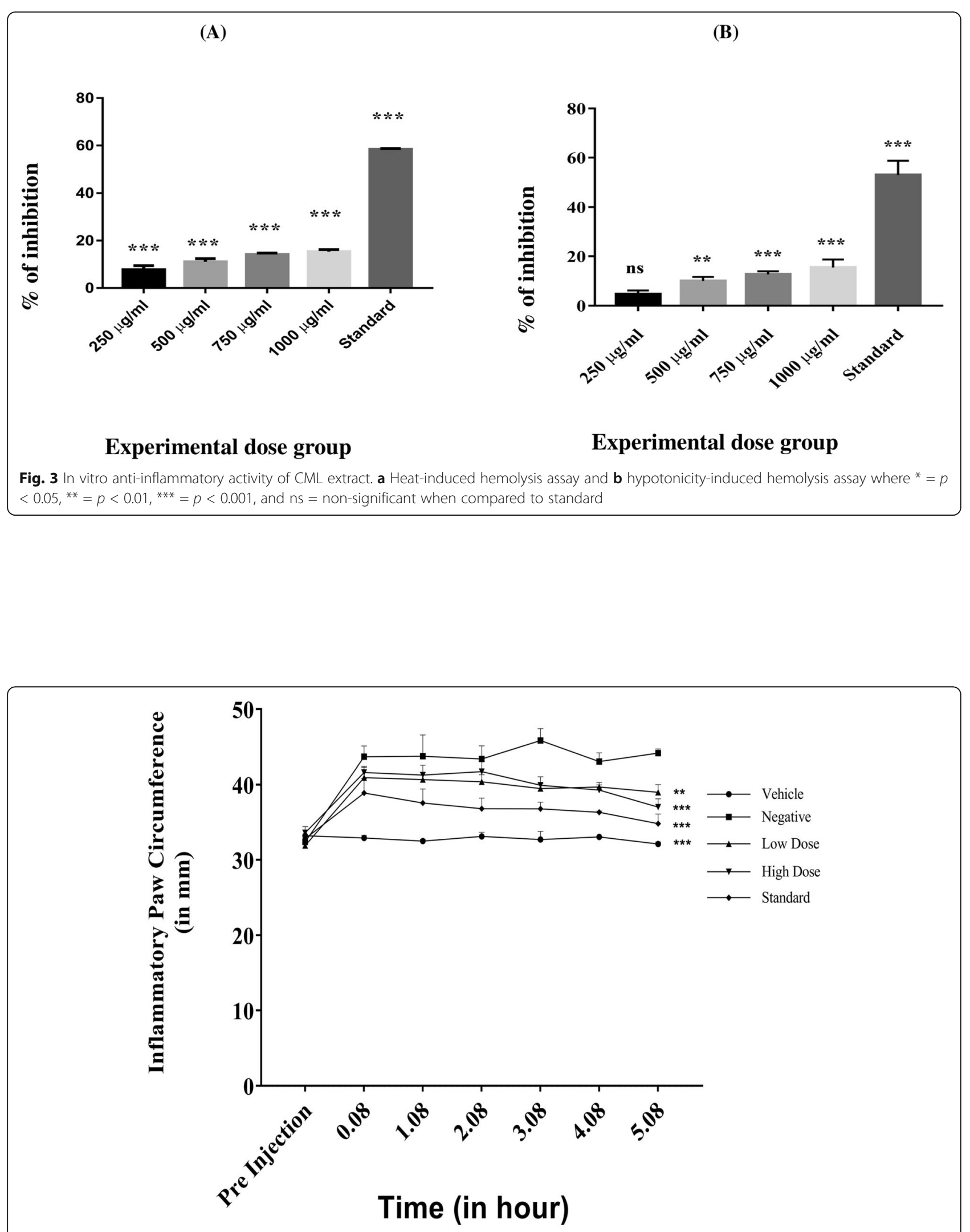

Fig. 4 Changes in paw circumference (in $\mathrm{mm}$ ) in carrageenan-induced paw swelling test against time (in min) in different experimental animal groups where ${ }^{*}=p<0.05,{ }^{* *}=p<0.01$, and ${ }^{* * *}=p<0.001$ 
Table 1 Change in paw circumference (in $\mathrm{mm}$ ) in different time intervals (in min) after the injection of carrageenan in the left hind paw of Wistar albino rats

\begin{tabular}{lllllllll}
\hline Groups & Pre-injection & $5 \mathrm{~min}$ & $65 \mathrm{~min}$ & $125 \mathrm{~min}$ & $185 \mathrm{~min}$ & $245 \mathrm{~min}$ & $305 \mathrm{~min}$ & $\%$ of inhibition \\
\hline Normal & $33.19 \pm 0.055$ & $32.91 \pm 0.24$ & $32.50 \pm 0.21$ & $33.11 \pm 0.54$ & $32.70 \pm 1.07$ & $33.04 \pm 0.04$ & $32.10 \pm 0.27$ & \\
Low dose & $31.89 \pm 0.56$ & $40.94 \pm 1.45$ & $40.68 \pm 0.90$ & $40.39 \pm 0.94$ & $39.49 \pm 0.64$ & $39.70 \pm 0.59$ & $38.97 \pm 1.01^{* *}$ & 39.94 \\
High dose & $33.59 \pm 0.83$ & $41.62 \pm 0.65$ & $41.28 \pm 1.27$ & $41.73 \pm 1.29$ & $39.91 \pm 1.12$ & $39.27 \pm 0.68$ & $37.00 \pm 1.09^{* * *}$ & 71.07 \\
Standard & $32.80 \pm 1.15$ & $38.90 \pm 1.92$ & $37.56 \pm 1.85$ & $36.81 \pm 1.39$ & $36.78 \pm 0.89$ & $36.32 \pm 0.17$ & $34.80 \pm 1.29^{* * *}$ & 83.03 \\
Negative & $32.38 \pm 0.40$ & $43.67 \pm 1.43$ & $43.76 \pm 2.81$ & $43.39 \pm 1.74$ & $45.83 \pm 1.57$ & $43.03 \pm 1.15$ & $44.17 \pm 0.53$ & \\
\hline
\end{tabular}

$*^{* *}=p<0.01,{ }^{* * *}=p<0.001$ when compared to normal negative control at the final hour of experiment, i.e., $6 \mathrm{~h} 5 \mathrm{~min}$

\section{Statistical analysis}

All qualitative data have been reported as the mean \pm SD of three measurements. Animal based experiments are expressed as mean \pm SEM. Statistical analysis and representation of statistical data were done using KyPlot version 5.0 (32 bit) and Graph Pad Prism version 7.00 for Windows (Graph pad Software Inc., San Diego, USA) using the one-way analysis of variance (ANOVA) followed by Dunnett's multiple comparison test, where $p$ $<0.001$ was considered as significant.

\section{Results}

Determination of hydrogen donating ability (DPPH assay) In the present antioxidant profiling, CML extract exhibited higher free radical scavenging activity (70.35 \pm 1.6 at $200 \mu \mathrm{g} / \mathrm{ml}$ ) than the respective standard (ascorbic acid) that showed a value $65.66 \pm 1.3$ at same concentration (Fig. 1a). This was evident from the development of yellow coloration after adding $\mathrm{DPPH}$. The $\mathrm{IC}_{50}$ value of the extract was found to be much lower, i.e., $58.47 \pm$ $2.27 \mu \mathrm{g} / \mathrm{ml}$.

\section{Hydroxyl radical scavenging assay}

CML significantly scavenge hydroxyl radical in a concentration dependent manner, i.e., at highest concentration $(200 \mu \mathrm{g} / \mathrm{ml}) \mathrm{OH}^{\cdot}$ radical scavenging percentage was $55.68 \pm 0.5$ as compared to its standard Mannitol (Fig. 1b) with $\mathrm{IC}_{50}$ value $91.14 \pm 1.1 \mu \mathrm{g} / \mathrm{ml}$.

\section{NO radical scavenging assay}

At $200 \mathrm{mg} / \mathrm{ml}$ concentration, percentage of inhibition of CML is moderately significant activity (63.96 \pm 1.8$)$ compared with standard curcumin (Fig. 1c). The $\mathrm{IC}_{50}$ value of CML extract was $70.87 \pm 0.8 \mu \mathrm{g} / \mathrm{ml}$.

\section{Iron chelating assay}

In the present study, CML was found to fade the color of ferrozine- $\mathrm{Fe}^{2+}$ complex, indicating its iron chelating activity due to presence of certain components. Moreover, the chelating percentage was found to $51.66 \pm 0.5$ at $1000 \mu \mathrm{g} / \mathrm{ml}$ (Fig. 2a).

\section{Measurement of reducing power}

The reducing power of CML extract was found to be increased in a dose dependent manner comparable to the reference compound BHT (Fig. 2b).

\section{Determination of total phenolic and flavonoid Content}

In this present study, the values of phenol and flavonoid were expressed as milligrams of gallic acid and quercetin equivalent per $1 \mathrm{~g}$ of CML. Total amount of phenol and
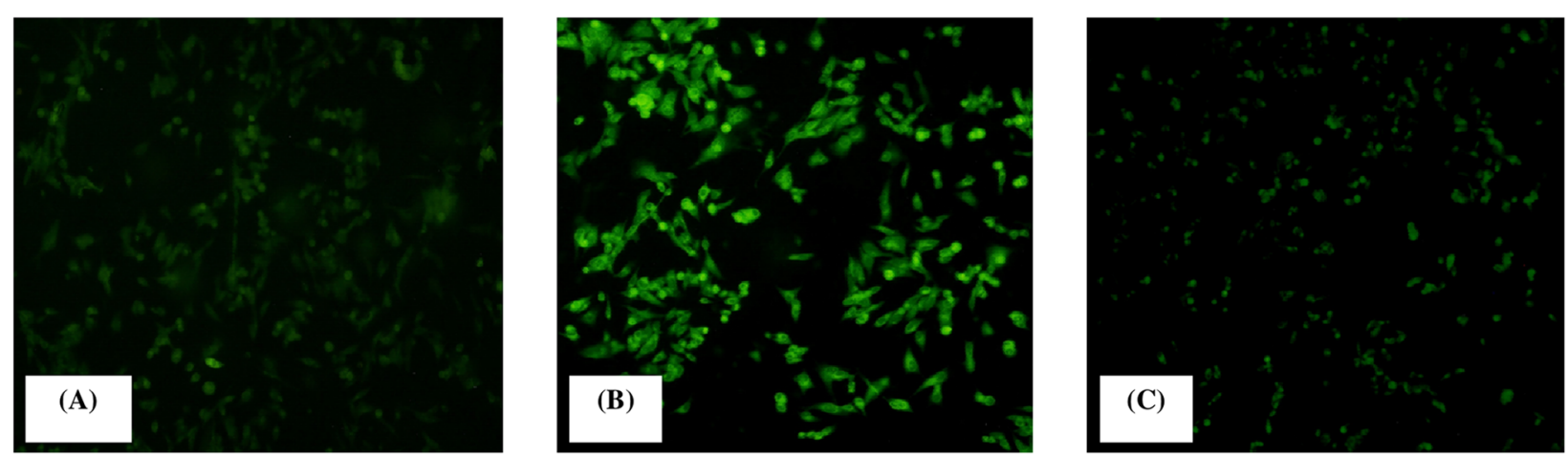

Fig. 5 Effects of CML in depletion of intracellular ROS production generated by $\mathrm{H}_{2} \mathrm{O}_{2}$ in $\mathrm{HepG} 2$ cells. Production of ROS was measured by cleavage of acetate group of non-fluorescent $\mathrm{H}_{2} \mathrm{DCFDA}\left(2^{\prime}, 7^{\prime}\right.$-dichlorodihydrofluorescein diacetate) which convert into DCF(2',7'-dichlorofluorescein) highly fluorescent. Cells were exposed to $\mathrm{H}_{2} \mathrm{O}_{2}$ before treatment with $\mathrm{CML}$ at $200 \mu \mathrm{g} / \mathrm{ml}$ for $24 \mathrm{~h}$. The ROS production displays the intensity of fluorescence through the images of $\mathrm{HepG} 2$ cells treated with different concentrations of $\mathrm{CML}$ : $\mathbf{a}$ control, $\mathbf{b} \mathrm{H}_{2} \mathrm{O}_{2}$, and $\mathbf{c} \mathrm{CML}$ extract 
(A)

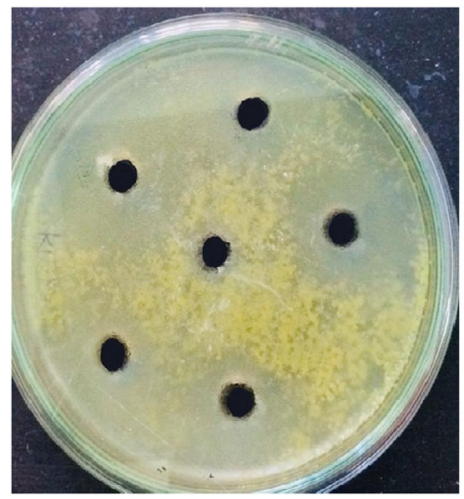

(B)

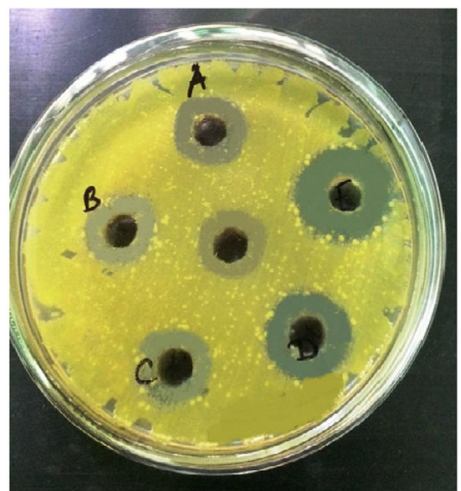

Fig. 6 a Antibacterial activity of CML extract against Staphylococcus sp. b MIC-calculating plate of CML against Staphylococcus sp.

flavonoid content of CML extract was $24.55 \pm 2.5 \mathrm{mg}$ and $10.76 \pm 0.09 \mathrm{mg}$ respectively.

\section{In vitro test of inflammation \\ Membrane stabilizing activity}

The experimental groups treated with CML extract showed excellent activity in membrane stabilization with a high significance for the heat-induced hemolysis test $(7.73 \pm 1.67,11.09 \pm 1.36,14.15 \pm 0.58$, and $15.36 \pm 0.89$ respectively for $250,500,750$, and $1000 \mu \mathrm{g} / \mathrm{ml}$ groups) (Fig. 3a). In the hypotonicity-induced hemolysis assay (Fig. 3b), the low-dose group $(250 \mu \mathrm{g} / \mathrm{ml})$ showed $4.55 \pm$ $0.90 \%$ inhibition at a non-significant level. The higherdose groups showed significant membrane lysis inhibition activity $(9.96 \pm 0.97,12.63 \pm 0.71$, and $15.40 \pm 1.9$ respectively for 500,750 , and $1000 \mu \mathrm{g} / \mathrm{ml}$ groups).
However, the inhibition of membrane lysis was highest in the standard indomethacin-treated groups $(200 \mu \mathrm{g} /$ $\mathrm{ml})$.

\section{In vivo test of inflammation \\ Acute toxicity test}

The CML extract up to the dose of $2 \mathrm{~g} / \mathrm{kg}$ body weight, showed no observable toxicological symptoms when fed for a single time.

\section{Carrageenan-induced paw edema test}

The low-dose group and high-dose groups (250 and $500 \mu \mathrm{g} / \mathrm{kg}$ b.w) showed a significant $39.94 \%$ and $71.07 \%$ (Fig. 4) of reduction in paw circumference respectively compared to untreated animals. The standard group, however, showed $83.03 \%$ reduction of paw swelling at a dose of $10 \mu \mathrm{g} / \mathrm{kg}$ b.w. (Table 1).

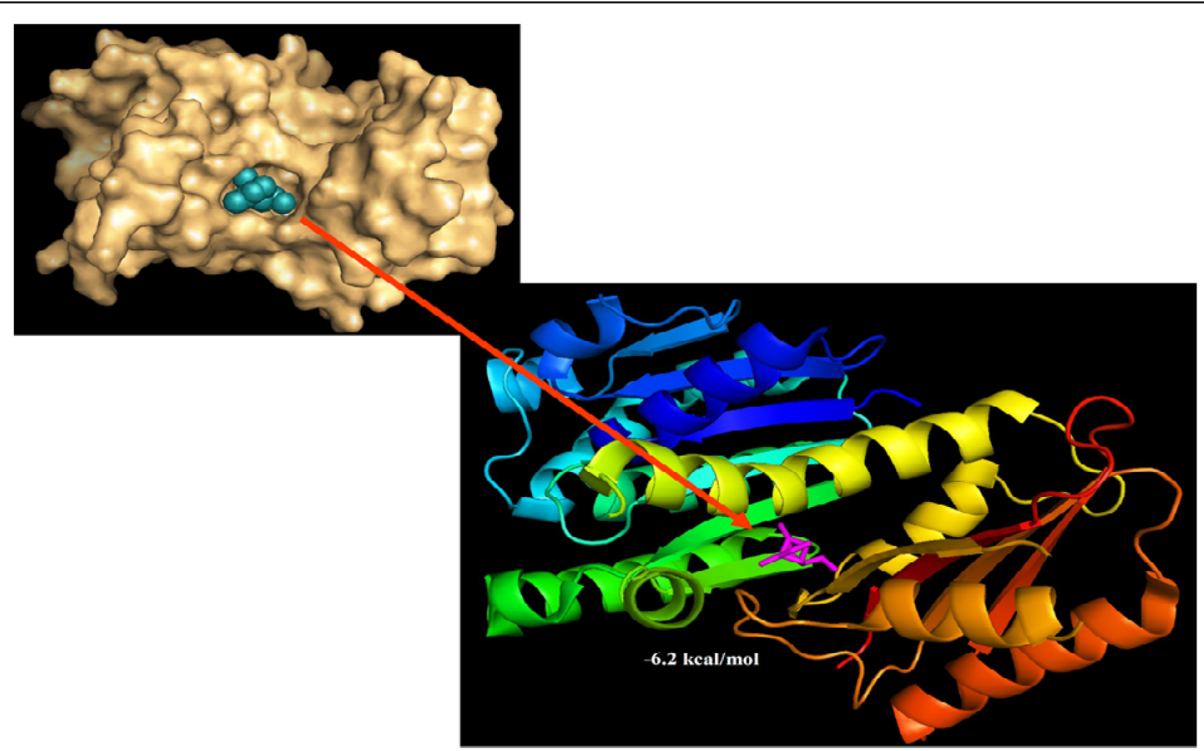

Fig. 7 Molecular docking of NF-KB (PDB id INFK) with selected ligand copaene 


\section{Measurement of ROS generation in HepG2 cell line}

Human liver carcinoma cell line HepG2 was used to examine the effects of CML under oxidative stress. $\mathrm{H}_{2} \mathrm{O}_{2}$ increases oxidative stress levels in the liver tissue. Therefore, HepG2 cells were treated with $\mathrm{H}_{2} \mathrm{O}_{2}$ for $0 \pm 24 \mathrm{~h}$, and intracellular oxidative levels were measured using the dichlorofluorescein assay. Figure 5 a showed the control cells. Figure $5 \mathrm{~b}$ demonstrated that cells exposed to $\mathrm{H}_{2} \mathrm{O}_{2}$ exhibited significantly increase in ROS levels. Tremendous decrease in fluorescence was detected at higher doses of CML $(200 \mu \mathrm{g} / \mathrm{ml})$ compared to the $\mathrm{H}_{2} \mathrm{O}_{2}$ (Fig. 5c).

\section{Microbiological screening Quantification of antimicrobial activity using agar well diffusion method}

The antimicrobial potential of CML extract was evaluated according to their zone of inhibition. At concentration $10 \mathrm{mg} / \mathrm{ml}$, CML showed inhibition zone $20 \pm 0.95$ $\mathrm{mm}$ against Staphylococcus sp. and $11 \pm 1.3 \mathrm{~mm}$ against Klebsiella sp. (Fig. 6). The antimicrobial activity was further established by molecular docking mechanism. We got the best docking result with copaene (Fig. 7), where the binding energy was $-6.2 \mathrm{kcal} / \mathrm{mol}$ (Table 2 ).

\section{Determination of MIC value using agar well diffusion method}

MIC value varied from $0.5 \mathrm{mg} / \mathrm{ml}$ to $2 \mathrm{mg} / \mathrm{ml}$ concentration. Among the five concentrations studied here, CML extract showed MIC $0.5 \mathrm{mg} / \mathrm{ml}$ in case of Staphylococcus sp. and $2 \mathrm{mg} / \mathrm{ml}$ in case of Klebsiella sp.

\section{GC-MS analysis}

Total 42 compounds were detected in GC-MS analysis. GC-MS results have depicted in Table 3.

\section{Molecular docking envisages the cross talk between NF-KB and selected ligands}

Menthone and proximadiol showed best binding affinities to $1 \mathrm{NF}-\mathrm{kB}$ (Fig. 8). The binding energies were -5.7 and $-5.6 \mathrm{kcal} / \mathrm{mol}$ (Table 4 ).

\section{Discussion}

The demand of antioxidants from natural origin has increased many folds because of their potential property to prevent and reduce the risk of several oxidative damage

Table 2 Different physiochemical properties of copaene

\begin{tabular}{ll}
\hline Molecular Weight & $204.357 \mathrm{~g} / \mathrm{mol}$ \\
\hline Hydrogen bond donor count & 0 \\
Hydrogen bond acceptor count & 0 \\
Rotatable bond count & 1 \\
XLogP3-AA & 4.5 \\
\hline
\end{tabular}

with minimal side effects (Aruoma 2003). In the present antioxidant profiling, CML leaf extract showed potential free radical scavenging activities. DPPH is a free radical that can accept an electron or hydrogen radical to become stable and reacts with reducing agent changing the color of the solution into pale yellow. Thus, DPPH scavenging activity by CML extract proves the presence of significant antioxidant properties. Human beings are exposed to $\mathrm{H}_{2} \mathrm{O}_{2}$ directly or indirectly via environment. This may produce hydroxyl radicals $(\mathrm{OH}$.) that can cause lipid peroxidation and DNA damage in the body (Huang et al. 2005). Therefore, the ability of CML extract to scavenge $\mathrm{H}_{2} \mathrm{O}_{2}$ proves beneficial for our health. Nitric oxide has an important role as pro-inflammatory mediators. During chronic inflammation iNOS (calciumindependent isoform of NOS) is activated by lipopolysaccharide and produces huge amount of nitric oxide. The active NO translocates NF- $\mathrm{k} \beta$ and leads to the formation of chronic inflammation (Misko et al. 2013). In the present study, it is described that nitric oxide is downregulated by CML extract. Thus, CML might inhibit the inflammation related disorders. Free iron is a potential enhancer of ROS formation as it leads to reduction of hydrogen peroxide and generation of the highly aggressive $\mathrm{OH}^{-}$. In the present study, CML fades the color of ferrozine complex, indicating its iron chelating activity due to presence of certain components. However, the reducing power assay was found to be lower when compared to the standard BHT. The phenolic compounds having redox potential show a significant role in neutralizing the free radicals, scavenging singlet, and triplet oxygen. Similarly, flavonoids have also been reported to exert its antioxidant activity, as they act on enzymes and pathways involved in anti-inflammatory processes (Mustafa et al. 2010).

The in vitro anti-inflammatory assessment provides a baseline understanding of the efficacy of a drug or traditional drug in the regulation of lysosomal membrane stabilization. Lysosomal vesicular fluid contains different enzymes and is inflammation inducer. Thus, a stabilized membrane provides a protection against inflammatory proceedings. Erythrocyte membranes are proved model system for the study of stabilization of lysosomal membranes due to their structural similarity (Anosike and Obidoa 2012). In our experiments, the experimental groups treated with CML extract showed excellent activity in membrane stabilization for both the heat-induced and hypotonicity-induced hemolysis assay. However, the inhibition of membrane lysis was highest in the standard indomethacin-treated groups $(200 \mu \mathrm{g} / \mathrm{ml})$. The carrageenan induces an inflammatory condition in the rodent paw and the histamines, serotonins, and prostaglandins play key roles in the progression of the process (Gupta et al. 2006). 
Table 3 List of different active phytochemicals identified by GC-MS analysis of the CML

\begin{tabular}{|c|c|c|c|}
\hline SI no. & Compound name & Formula & RT \\
\hline 1. & L-menthyl chloroformate & $\mathrm{C}_{11} \mathrm{H}_{19} \mathrm{ClO}_{2}$ & 8.418 \\
\hline 2. & Dodecane & $\mathrm{C}_{12} \mathrm{H}_{26}$ & 8.857 \\
\hline 3. & 1,8-cineole & $\mathrm{C}_{10} \mathrm{H}_{18} \mathrm{O}$ & 9.809 \\
\hline 4. & D-menthone & $\mathrm{C}_{10} \mathrm{H}_{18} \mathrm{O}$ & 13.461 \\
\hline 5. & Dimethyl ester of dimethylmalonic acid & $\mathrm{C}_{7} \mathrm{H}_{12} \mathrm{O}_{4}$ & 19.066 \\
\hline 6. & Alpha-copaene & $\mathrm{C}_{15} \mathrm{H}_{24}$ & 19.639 \\
\hline 7. & 2-methylaminobenzoic acid methyl ester & $\mathrm{C}_{9} \mathrm{H}_{11} \mathrm{NO}_{2}$ & 20.380 \\
\hline 8. & n-pentadecanal & $\mathrm{C}_{15} \mathrm{H}_{30} \mathrm{O}$ & 27.738 \\
\hline 9. & Tetradecanoic acid & $\mathrm{C}_{14} \mathrm{H}_{28} \mathrm{O}_{2}$ & 28.668 \\
\hline 10. & Neophytadiene & $\mathrm{C}_{20} \mathrm{H}_{38}$ & 30.334 \\
\hline 11. & 3,7,11,15-tetramethyl-2-hexadecen-1-ol & $\mathrm{C}_{20} \mathrm{H}_{9} \mathrm{O}$ & 30.833 \\
\hline 12. & 3-eicosyne & $\mathrm{C}_{20} \mathrm{H}_{38}$ & 31.205 \\
\hline 13. & Hexadecanoic acid, 2-oxo-, methyl ester & $\mathrm{C}_{17} \mathrm{H}_{32} \mathrm{O}_{3}$ & 31.267 \\
\hline 14. & Furan, 2-octyl & $\mathrm{C}_{10} \mathrm{H}_{19} \mathrm{Cl}$ & 31.719 \\
\hline 15. & Hexadecanal & $\mathrm{C}_{16} \mathrm{H}_{32} \mathrm{O}$ & 31.995 \\
\hline 16. & Hexadecanoic acid, methyl ester & $\mathrm{C}_{17} \mathrm{H}_{34} \mathrm{O}_{2}$ & 32.105 \\
\hline 17. & 3-(4,8,12-trimethyltridecyl) furan & $\mathrm{C}_{20} \mathrm{H}_{36} \mathrm{O}$ & 32.175 \\
\hline 18. & Pentadecanoic acid & $\mathrm{C}_{15} \mathrm{H}_{30} \mathrm{O}_{2}$ & 32.783 \\
\hline 19. & Cyclopropanecarboxylic acid, oct-3-en-2-yl ester & $\mathrm{C}_{12} \mathrm{H}_{20} \mathrm{O}_{2}$ & 33.117 \\
\hline 20. & Hexadecanoic acid, 2-oxo-, methyl ester & $\mathrm{C}_{17} \mathrm{H}_{32} \mathrm{O}_{3}$ & 33.293 \\
\hline 21. & Hexadecanoic acid, trimethylsilyl ester & $\mathrm{C}_{19} \mathrm{H}_{40} \mathrm{O}_{2} \mathrm{Si}$ & 34.423 \\
\hline 22. & Octadecanoic acid, methyl ester & $\mathrm{C}_{19} \mathrm{H}_{38} \mathrm{O}_{2}$ & 35.917 \\
\hline 23. & $2 \mathrm{n}$ heptylcyclopentanone & $\mathrm{C}_{12} \mathrm{H}_{22} \mathrm{O}$ & 36.680 \\
\hline 24. & Trimethylsilyl (9e)-9-octadecenoate & $\mathrm{C}_{21} \mathrm{H}_{42} \mathrm{O}_{2} \mathrm{Si}$ & 37.589 \\
\hline 25. & 2 ethylcyclohexanol, bromomethyldimethylsilyl ether & $\mathrm{C}_{11} \mathrm{H}_{23} \mathrm{BrOSi}$ & 38.697 \\
\hline 26. & 1-nonadecene & $\mathrm{C}_{19} \mathrm{H}_{38}$ & 38.763 \\
\hline 27. & Methyl 10-oxooctadecanoate & $\mathrm{C}_{19} \mathrm{H}_{36} \mathrm{O}_{3}$ & 38.818 \\
\hline 28. & Cyclohexane, decyl & $\mathrm{C}_{16} \mathrm{H}_{32}$ & 39.261 \\
\hline 29. & Benzyl(dimethyl)silyl methyl decanedioate & $\mathrm{C}_{20} \mathrm{H}_{32} \mathrm{O}_{4} \mathrm{Si}$ & 39.366 \\
\hline 30. & 7-isopropyl-10-methyl-1,5-dithiaspiro[5.5]undecane & $\mathrm{C}_{13} \mathrm{H}_{24} \mathrm{~S}_{2}$ & 39.537 \\
\hline 31. & 1-henicosanol & $\mathrm{C}_{21} \mathrm{H}_{44} \mathrm{O}$ & 39.763 \\
\hline 32. & 1-glyceryl linoleate & $\mathrm{C}_{21} \mathrm{H}_{38} \mathrm{O}_{4}$ & 40.054 \\
\hline 33. & Oleoyl chloride & $\mathrm{C}_{18} \mathrm{H}_{33} \mathrm{ClO}$ & 40.112 \\
\hline 34. & 1-hexadecanol, 3,7,11,15-tetramethyl & $\mathrm{C}_{20} \mathrm{H}_{42} \mathrm{O}$ & 40.346 \\
\hline 35. & (1-propylnonyl)cyclohexane & $\mathrm{C}_{18} \mathrm{H}_{36}$ & 41.154 \\
\hline 36. & Proximadiol & $\mathrm{C}_{15} \mathrm{H}_{28} \mathrm{O}_{2}$ & 41.508 \\
\hline 37. & Acetylenedicarboxylic acid, di-(-)-menthyl- & $\mathrm{C}_{24} \mathrm{H}_{38} \mathrm{O}_{4}$ & 42.167 \\
\hline 38. & 10-undecenyl laurate & $\mathrm{C}_{23} \mathrm{H}_{44} \mathrm{O}_{2}$ & 42.697 \\
\hline 39. & Spermidine & $\mathrm{C}_{7} \mathrm{H}_{19} \mathrm{~N}_{3}$ & 43.406 \\
\hline 40. & Cholest-1-eno[2,1-a]naphthalene, 3',4'-dihydro & $\mathrm{C}_{35} \mathrm{H}_{52}$ & 44.434 \\
\hline 41. & Pregnane-3,11,20,21-tetrol, cyclic 20,21-(1,1-dimethylethyl) & $\mathrm{C}_{25} \mathrm{H}_{43} \mathrm{BO}_{4}$ & 45.945 \\
\hline 42. & Stigmast-5-en-3-ol, (3.BETA.) & $\mathrm{C}_{29} \mathrm{H}_{50} \mathrm{O}$ & 47.248 \\
\hline
\end{tabular}


(A)

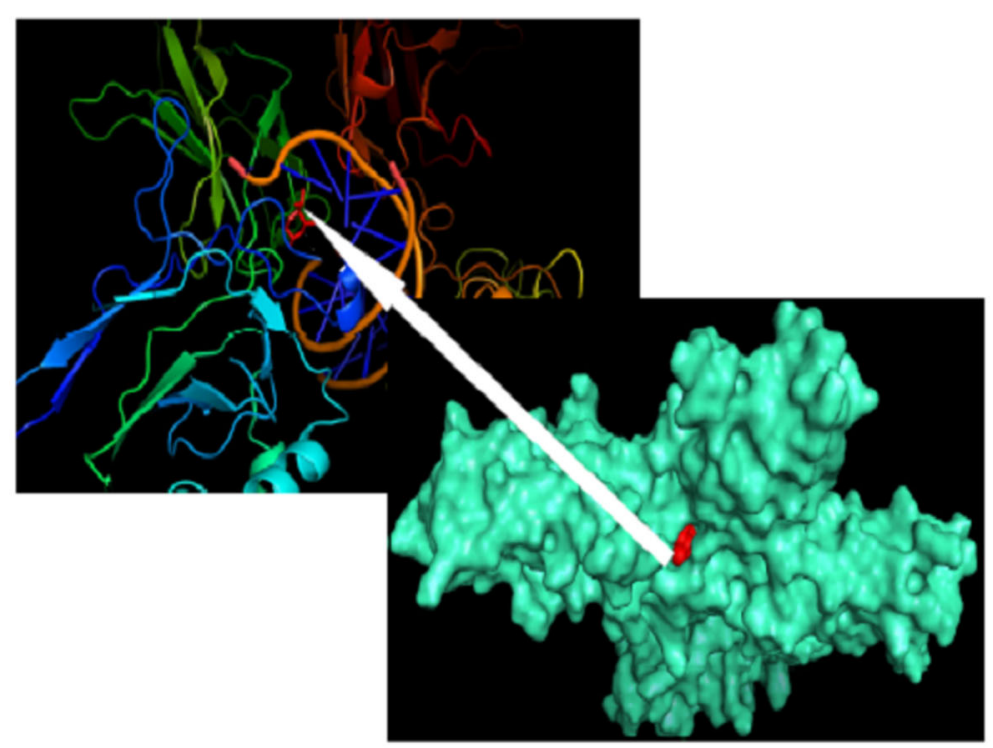

(B)

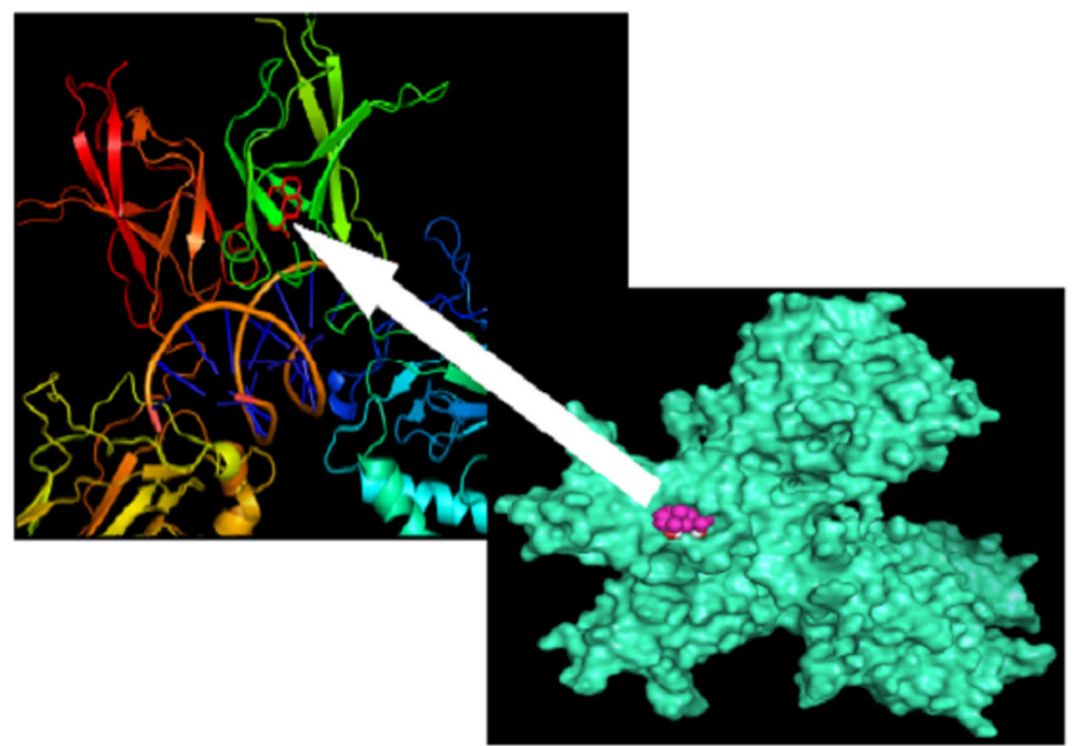

Fig. 8 Molecular docking of NF-KB (PDB id INFK) with selected ligand a menthone and $\mathbf{b}$ proximadiol

The experiment indicates that the oral administration of CML is efficient in the inhibition of inflammation in carrageenan-injected animals with a high percentage $(71 \%)$. The result indicates that the CML is a potent anti-inflammatory agent when used in the in vivo systems. The synergistic effect of the different bioactive compounds present in the CML extract could have a vital role in this regard.
Hydrogen peroxide $\left(\mathrm{H}_{2} \mathrm{O}_{2}\right)$ is a stable free radical having important role in signaling pathways (Wu and Yotnda 2011). Oxidative stress is associated with increased levels of ROS productions in living cell. $\mathrm{H}_{2}$ DCFDA was used to distinguish the production of intracellular ROS generation. $\mathrm{H}_{2}$ DCF-DA recognized hydrogen peroxide by exhibiting fluorescence on HepG2 cell line exposed to $\mathrm{H}_{2} \mathrm{O}_{2}$, as it induced oxidative stress.

Table 4 Phytochemical properties of two selected compounds found from CML extract trough GC-MS analysis

\begin{tabular}{llllll}
\hline Compounds & Rotatable bond count & MW g/mol & H-donar & H-acceptor & XLogP \\
\hline Menthone & 1 & 154.253 & 0 & 1 & 2.7 \\
Proximadiol & 1 & 240.387 & 2 & 2 & 3 \\
\hline
\end{tabular}


However, a considerable reduction in fluorescence intensity was seen with CML-treated group. This suggests that under the impact of CML, $\mathrm{H}_{2} \mathrm{O}_{2}$-induced ROS was reduced proportionately. From this experiment, it might be figured that CML plays an important role in reducing the impact of $\mathrm{H}_{2} \mathrm{O}_{2}$ on normal intracellular function.

In the antimicrobial assay, based upon inhibition zone, it is clearly shown that the CML extract is very effective against gram positive than the gram-negative bacteria with a lower MIC value.

Several compounds with potential therapeutic significance have been detected with the help of GC-MS analysis. Several phytochemicals belonging to long chain fatty moiety and their derivatives such as hexadecanoic acid, octadecadienoic acid, and phytol have been identified in the samples. Interestingly, these long chain fatty acids play an important role in plant development. Out of 42 compounds found in CML, neophytadiene has anti-cancerous and anti-proliferative activity (Arora and Kumar 2018). Proximadiol has been used as antispasmodic drug (Evans et al. 1982). Stigmasterol which is a good antioxidant compound also shows hypoglycemic and thyroid inhibiting activity (Panda et al. 2009). Nonadecene has cytotoxic activities; besides, it is good antifungal and anticancer agent (Arora and Kumar 2018).

In silico docking of two phytocompounds with the protein NF- B had shown to follow the Lipinski's rule of five. It is the rule which evaluates the drug likeliness of a subject compound, i.e., whether the experimental phytocompounds would fall under the criteria of a drug or not (Ogungbe et al. 2014). Here, menthone and proximadiol which we got in GC-MS analysis obeyed the all five criteria of Lipinski's rule. Thus, the binding efficacy of menthone and proximadiol with NF- $\beta$ protein supporting its uptake as anti-inflammatory agent.

The ROS plays a very important role in the generation of inflammatory conditions. Inflammation is a basic property of the cells elicited during its damage or poor health. Chronic inflammation can be seen in case of arthritis and even leads to cancer. The different antioxidant experiments reveal that the CML has potency to downregulate the quantity of ROS generated from different sources. In the in vivo system, carrageenan induces the activation of NF-kB which increases IL-8 cytokine production. This cytokine is a pro-inflammatory cytokine and helps in the upregulation of inflammation. In this well-known pathway, NF-kB plays the vital role and the same molecule was seen to interact with the active phytocompounds of CML in silico which further strengthens our assumption. We assumed a probable involvement of the CML phytocompounds with some of the prime inflammatory molecules that could hinder the progression of inflammation. In the other hand, many authors have described the role of synergy in the complementary medications where more than one compounds play vital role in disease amelioration and inhibits the disease more efficiently (Anilakumar et al. 2010). The in silico study provides a strong prediction of such interaction and establishes the usage of this herbal remedy as the subject of complementary medication.

\section{Conclusion}

Human cells have a tendency of generating ROS in day to day activities. Over production of ROS generally shifts cells oxidant-antioxidant pool. Besides, over production of these reactive oxygen species are involved in liver damage, kidney dysfunction, aging-related disorders, and inflammation. Juice of Citrus is known for ages as important health drink and several works have been done including the juices of $C$. macroptera. However, the activity of leaf extract of $C$. macroptera on human is largely elusive. In the present study, we have shown that CML extract is not only rich in antioxidant, but also is capable enough to cure selected ROS-related ailments particularly tissue inflammation. Our in vitro study was supported by in vivo evaluation on Wistar rat as well as by the in silico docking results. Therefore, it is evident from the present study that the leaf extract of C. macroptera could be a value addition in the list of health product related to Citrus. However, further study is required before its commercialization.

\section{Abbreviations \\ DPPH: 2,2-diphenyl-1-picrylhydrazyl; ROS: Reactive oxygen species; CML: Citrus macroptera leaf; MIC: Minimum inhibitory concentration; NO: Nitric oxide; $\mathrm{H}_{2}$ DCF: 2,7-dichlorofluorescein; $\mathrm{H}_{2}$ DCFDA: 2,7- dichlorodihydrofluorescein}

\section{Authors' contributions}

AS conceived the idea. AS, ML, SP, DM, AD, and SB designed the experiments. $M L, D M, S P$, and AD carried out the experiments. IS designed and analyzed the in silico portion. AK performs the ROS experiment. All the authors contributed in drafting the manuscript and approved it.

Funding

Not applicable.

\section{Availability of data and materials}

All data including the results are provided within the article.

\section{Ethics approval}

All the experiments using animals were monitored, reviewed, and approved by the Animal Ethical Committee of Department of Zoology, NBU (Permit No. 840/ac/04/CPCSEA, Committee for the Purpose of Control and Supervision of Experiments on Animals).

\section{Competing interests}

The authors declare that there are no competing interests.

\section{Author details}

${ }^{1}$ Molecular Cytogenetics Laboratory, Department of Botany, University of North Bengal, Siliguri, West Bengal, India. ${ }^{2}$ Cell and Molecular Biology Laboratory, Department of Zoology, University of North Bengal, Siliguri, West Bengal, India. ${ }^{3}$ ANMOL Laboratory, Department of Biotechnology, University of North Bengal, Siliguri, West Bengal, India. 
Received: 24 May 2019 Accepted: 4 May 2020

Published online: 29 May 2020

\section{References}

Ahmed AU (2011) An overview of inflammation: mechanism and consequences. Front Biol 6(4):274

Akinyemi KO, Oladapo O, Okwara CE, Ibe CC (2005) Fasure KA Screening of crude extracts of six medicinal plants used in South-West Nigerian unorthodox medicine for anti-methicillin resistant Staphylococcus aureus activity. BMC Complement Altern Med 5:6

Anilakumar KR, Sudarshanakrishna KR, Chandramohan G, llaiyaraja N, Khanum F, Bawa AS (2010) Effect of Aloe vera gel extract on antioxidant enzymes and azoxymethane-induced oxidative stress in rats. Indian J Exp Biol 48(8):837842

Anosike CA, Obidoa O (2012) Ezeanyika LUS Membrane stabilization as a mechanism of the anti-inflammatory activity of methanol extract of garden egg (Solanum aethiopicum). DARU J Pharma Sci 20:76

Arora S, Kumar G (2018) Phytochemical screening of root, stem and leaves of Cenchrus biflorus Roxb. J Pharmacognosy Phytochem 7:1445-1450

Aruoma OI (2003) Methodological considerations for characterizing potential antioxidant actions of bioactive components in plant foods. Mut Res Fundamental Mol Mechan Mutagenesis 523:9-20

Balaydin HT, Gulcin I, Menzek A, Goksu S, Sahin E (2010) Synthesis and antioxidant properties of diphenylmethane derivative bromophenols including a natural product. J Enzyme Inhibit Med Chem 25:685-695

Borthakur A, Bhattacharyya S, Anbazhagan AN, Kumar A, Dudeja PK, Tobacman JK (2012) Prolongation of carrageenan-induced inflammation in human colonic epithelial cells by activation of an NFKB-BCL 10 loop. Biochimica et Biophysica Acta (BBA)-Molecular Basis of Disease 1822:1300-1307

Bulkley GB (1983) The role of oxygen free radicals in human disease processes. Surgery 94:407-411

Bursal E, Koksal E, Gulcin I, Bilsel G, Goren AC (2013) Antioxidant activity and polyphenol content of cherry stem (Cerasus avium L.) determined by LC-MS/ MS. Food Res Int 51:66-74

Cheung CK, Wyman JF, Halcon LL (2007) Use of complementary and alternative therapies in community-dwelling older adults. J Altern Complement Med 13: 997-1006

Corley DA, Kerlikowske K, Verma R, Buffler P (2003) Protective association of aspirin/NSAIDs and esophageal cancer: a systematic review and metaanalysis. Gastroenterology 124:47-56

Dey P, Dutta S, Sarkar MP, Chaudhuri TK (2015) Assessment of hepatoprotective potential of $\mathrm{N}$. indicum leaf on haloalkane xenobiotic induced hepatic injury in Swiss albino mice. Chem Biol Interact 235:37-46

Evans FE, Miller DW, Cairns T, Baddeley GV, Wenkert E (1982) Structure analysis of proximadiol (cryptomeridol) by 13C [carbon isotope] NMR spectroscopy [Cymbopogon proximus]. Phytochemistry 21:937-938

Gross C, Hen R (2004) The developmental origins of anxiety. Nat Rev Neurosci 5: 545

Guan F, Yu J, Yu J, Liu Y, Li Y, Feng X, Huang KC, Chang Z, Ye S (2018) Lateral interactions between protofilaments of the bacterial tubulin homolog FtsZ are essential for cell division. eLife 7:e35578. https:/doi.org/10.7554/eLife. 35578

Gupta AK, Parasar D, Sagar A, Choudhary V, Chopra BS, Garg R, Khatri N (2015) Analgesic and anti-inflammatory properties of gelsolin in acetic acid induced writhing, tail immersion and carrageenan induced paw edema in mice. PLoS One 10:e0135558

Gupta M, Mazumder UK, Gomathi P, Selvan VT (2006) Antiinflammatory evaluation of leaves of Plumeria acuminata. BMC Complement Altern Med 6: 36

Hanelt P Institute of plant genetics and crop plant research (Eds.)(2001): Mansfeld's Encyclopedia of Agricultural and Horticultural Crops. Springer, Berlin etc 1, no. 6 (2017): 3716

Huang D, Ou B, Prior RL (2005) The chemistry behind antioxidant capacity assays. J Agric Food Chem 53:1841-1856

Misko TP, Radabaugh MR, Highkin M, Abrams M, Friese O, Gallavan R, Bramson C, Le Graverand MPH, Lohmander LS, Roman D (2013) Characterization of nitrotyrosine as a biomarker for arthritis and joint injury. Osteoarthr Cartil 21: $151-156$

Modak D, Paul S, Bhattacharjee S (2017) Anti-inflammatory activity of Acmella uliginosa (sw) cass. flower methanolic extract on membrane stabilization and protein denaturation: an in-vitro evaluation. NBU J Anim Sc 11:61-69
Mustafa RA, Hamid AA, Mohamed S, Bakar FA (2010) Total phenolic compounds, flavonoids, and radical scavenging activity of 21 selected tropical plants. J Food Sci 75:C28-C35

Ogungbe IV, Erwin WR, Setzer WN (2014) Antileishmanial phytochemical phenolics: molecular docking to potential protein targets. J Mol Graph Mode 48:105-117

Olurinola PF (1996) A laboratory manual of pharmaceutical microbiology: Nigeria: Idu. Abuja 69:1-105

Osadebe PO, Okoye FBC (2003) Anti-inflammatory effects of crude methanolic extract and fractions of Alchornea cordifolia leaves. J Ethnopharmacol 89:1924

Panda S, Jafri M, Kar A, Meheta BK (2009) Thyroid inhibitory, antiperoxidative and hypoglycemic effects of stigmasterol isolated from Butea monosperma. Fitoterapia 80:123-126

Paul S, Hossen MS, Tanvir EM, Islam MA, Afroz R, Ahmmed I, Saha M, Gan SH, Khalil MI (2015) Antioxidant properties of citrus macroptera fruit and its in vivo effects on the liver, kidney and pancreas in wistar rats. Int J Pharmacol 11:899-909

Rahman H, Eswaraiah MC, Dutta A (2014) Neuropharmacological activities of ethanolic extract of Citrus macroptera (Varannamensis) fruit peels. Global J Pharmacol 8:609-616

Saha MR, Dey P, Begum S, De B, Chaudhuri TK, De Sarker D, Das AP, Sen A (2016) Effect of Acacia catechu (Lf) Willd. on oxidative stress with possible implications in alleviating selected cognitive disorders. PLoS One 11: e0150574

Sheir Z, Nasr AA, Massoud A, Salama O, Badra GA, El-Shennawy H, Hassan N, Hammad SM (2001) A safe, effective, herbal antischistosomal therapy derived from myrrh. Am J Trop Med Hygiene 65:700-704

Shinde UA, Phadke AS, Nair AM, Mungantiwar AA, Dikshit VJ, Saraf MN (1999) Membrane stabilizing activity -a possible mechanism of action for the antiinflammatory activity of Cedrus deodara wood oil. Fitoterapia 70:251-257

Singleton VL, Rossi JA (1965) Colorimetry of total phenolics with phosphomolybdic-phosphotungstic acid reagents. Am J Enol Vitic 16:144158

Stadtman ER (1992) Protein oxidation and aging. Science 257:1220-1224

Uddin N, Hasan MR, Hasan MM, Hossain MM, Alam MR, Hasan MR, Islam AFMM, Rahman T, Rana MS (2014) Assessment of toxic effects of the methanol extract of Citrus macroptera Montr. fruit via biochemical and hematological evaluation in female Sprague-Dawley rats. PLoS One 9:e111101

Wu D, Yotnda P (2011) Production and detection of reactive oxygen species (ROS) in cancers. J Vis Exp 57:e3357

Zhishen J, Mengcheng T, Jianming W (1999) The determination of flavonoid contents in mulberry and their scavenging effects on superoxide radicals. Food Chem 64:555-559

\section{Publisher's Note}

Springer Nature remains neutral with regard to jurisdictional claims in published maps and institutional affiliations.

\section{Submit your manuscript to a SpringerOpen ${ }^{\circ}$ journal and benefit from:}

- Convenient online submission

- Rigorous peer review

- Open access: articles freely available online

- High visibility within the field

- Retaining the copyright to your article

Submit your next manuscript at $\boldsymbol{\nabla}$ springeropen.com 